\title{
Nutrient Uptake Response of New Guinea Impatiens to Light, Temperature, and Nutrient Solution Concentration
}

\author{
Kyle R. Mankin ${ }^{1}$ \\ Department of Biological and Agricultural Engineering, Kansas State University, Manhattan, \\ KS 66506-2906 \\ R. Peter Fynn ${ }^{2}$ \\ Department of Agricultural Engineering, Ohio Agricultural Research and Development Center, The Ohio \\ State University, Wooster, OH 44691 \\ Additional index words. controlled environment, greenhouse, hydroponics, modeling, irrigation, water quality, Impatiens $\mathrm{X}$ hb
}

\begin{abstract}
Nutrient uptake by New Guinea impatiens (Impatiens $\boldsymbol{X} \boldsymbol{h b}$.) 'Equinox' was measured in a growth chamber under various combinations of light [photosynthetic photon flux (PPF)], air temperature, and nutrient solution concentration. Nitrate-N, P, K, Ca, and Mg ions were evaluated individually by measuring depletion of each nutrient from a constantvolume solution over 9 hours with constant environmental conditions. Individual nutrient uptake was not correlated to concurrent daily temperature environment, and only $\mathrm{K}$ and $\mathrm{Mg}$ showed a correlation with PPF. Uptake rates of N, P, K, $\mathrm{Ca}$, and $\mathrm{Mg}$ increased significantly with increasing nutrient solution concentration. Estimated net assimilation rates of nutrients, based on measured shoot tissue concentrations of each nutrient and assuming that uptake occurred continuously at a rate proportional to canopy area, were correlated to average measured uptake rates for $\mathrm{N}, \mathrm{Ca}$, and $\mathrm{Mg}$ and were not correlated to average uptake rates for $P$ and $K$. Although nutrient demand from plant growth may determine rates of nutrient uptake necessary over longer periods of time, short-term uptake was not related directly to daily fluctuations in environmental factors.
\end{abstract}

Concern over water quality has brought increased scrutiny to nutrient management practices in commercial greenhouses. Relatively inexpensive water and nutrients can easily be applied at high rates to ensure vigorous plant growth. Nutrients applied in excess of actual plant uptake may be leached out of containers or away from the root zone into soil, surface water, or groundwater outside the greenhouse (Biernbaum and Fonteno, 1989; McAvoy et al., 1992; Morisot et al., 1978). Willits et al. (1992) concluded that "increasing concerns about environmental pollution coupled with recent advances in the ability to control the environment of greenhouses via computers have made it necessary and possible to consider adjusting nutrient solutions to minimize waste and maximize growth." However, what amount of nutrients should be applied and when to achieve minimum waste and maximum growth?

A framework for answering these questions was presented in a model proposed by Mankin and Fynn (1996). In this model, the rate of nutrient uptake was related to current plant nutrient demand, which in turn was determined by rates of plant photosynthesis or growth. Assuming insignificant plant storage of nutrients (Bloom et al., 1985) and no dark-period nutrient uptake (Pang, 1992), nutrient uptake would be directly related to current or near-term,

Received for publication 20 Sept. 1995. Accepted for publication 3 May 1996. Ohio Agricultural Research and Development Center (OARDC) manuscript no. 142-95. Salaries and research support provided by state and federal funds appropriated to the OARDC, The Ohio State Univ. Additional support was provided by a grant from The Bedding Plants Foundation. K.R.M. was supported by an OARDC Director's Fellowship and the Charles E. Thorne Memorial Assistantship. Use of trade names does not imply endorsement of the products named or criticism of similar ones omitted. The cost of publishing this paper was defrayed in part by the payment of page charges. Under postal regulations, this paper therefore must be hereby marked advertisement solely to indicate this fact.

${ }^{1}$ Assistant professor.

${ }^{2}$ Assistant professor. light-period environmental conditions. Two important environmental factors in this model were photosynthetic photon flux (PPF) and air temperature, both of which are easily measured and could be used as inputs to a nutrient-demand model. In addition to nutrient demand, nutrient supply also has affected nutrient uptake (see reviews by Epstein, 1973; Mankin and Fynn, 1996; Nissen, 1991). Together, these factors could be used to determine rate and timing of nutrients in plant fertilization management systems. Our objectives were 1) to quantify the effects of nutrient solution concentration, $\mathrm{PPF}$, and air temperature on uptake of $\mathrm{N}, \mathrm{P}, \mathrm{K}, \mathrm{Ca}$, and $\mathrm{Mg}$ and 2) to evaluate the validity of assuming that nutrient uptake responds directly to short-term environmental conditions.

\section{Materials and Methods}

A walk-in growth chamber (Mankin, 1994) was used for our study and was instrumented according to established growth chamber guidelines (American Society of Agricultural Engineers, 1986). New Guinea impatiens (Impatiens $X$ hb.) 'Equinox’ were grown in pots $(10 \mathrm{~cm}$ in diameter) with Haydite Grade $\mathrm{H}$ media (sorted, expanded shale gravel; Hydraulic Press Brick Co., Cleveland). Plants (36) were arranged on each of four $1.2-\mathrm{m}^{2}$ benches to receive symmetrical lighting beneath fifteen $400-\mathrm{W}$ lamps: eight high-pressure sodium and seven metal halide. Shoots extended through slot openings in a black polyethylene sheet that covered pots and free bench surfaces to retard evaporation. Drip emitters supplied each pot with a continuous flow of irrigation solution at $20 \mathrm{ml} \cdot \mathrm{min}^{-1}$. Each of the four independent bench irrigation systems maintained a constant $6.5-\mathrm{L}$ volume using automated additions of distilled-deionized water from a common tank.

Potted plants were relocated from a greenhouse to the growth chamber $18 \mathrm{~d}$ after transplantation as rooted cuttings. The experiment started 8 days later, when plants were $\approx 54 \mathrm{~d}$ old, and concluded 9 weeks later when plants were $114 \mathrm{~d}$ old. Ten plants 
Table 1. Randomization of experimental treatments. Nutrient recipes are expressed as a fraction or multiple of a standard $(1 \mathrm{x})$ baseline recipe.

\begin{tabular}{|c|c|c|c|c|c|c|c|c|c|c|}
\hline \multirow[b]{3}{*}{ Week } & \multicolumn{4}{|c|}{ Nutrient recipe } & \multirow{3}{*}{$\begin{array}{c}\text { Temp } \\
\left({ }^{\circ} \mathrm{C}\right)\end{array}$} & \multicolumn{5}{|c|}{$\mathrm{PPF}^{\mathrm{z}}$ level (rated \% transmission) } \\
\hline & \multicolumn{4}{|c|}{ Bench } & & \multicolumn{5}{|c|}{ Day } \\
\hline & 1 & 2 & 3 & 4 & & 1 & 2 & 3 & 4 & 5 \\
\hline 1 & $+1 / 2 \mathrm{x}$ & $2 \mathrm{x}$ & $+1 / 4 \mathrm{x}$ & $1 \mathrm{x}$ & 25 & 20 & 100 & 70 & 37 & $\overline{53}$ \\
\hline 2 & $+1 / 2 \mathrm{x}$ & $2 \mathrm{x}$ & $1 \mathrm{x}$ & $+1 / 4 \mathrm{x}$ & 30 & 70 & 53 & 20 & 37 & 100 \\
\hline 3 & $+1 / 4 \mathrm{x}$ & $+1 / 2 \mathrm{x}$ & $1 \mathrm{x}$ & $2 \mathrm{x}$ & 20 & 53 & 70 & 37 & 20 & 100 \\
\hline 4 & $1 \mathrm{x}$ & $+1 / 2 \mathrm{x}$ & $2 \mathrm{x}$ & $+1 / 2 \mathrm{x}$ & 30 & 100 & 20 & 53 & 70 & 37 \\
\hline 5 & $+1 / 4 \mathrm{x}$ & $1 \mathrm{x}$ & $2 x$ & $+1 / 2 \mathrm{x}$ & 20 & 20 & 53 & 100 & 37 & 70 \\
\hline 6 & $1 x$ & $2 x$ & $+1 / 4 \mathrm{x}$ & $+1 / 2 \mathrm{x}$ & 25 & 37 & 53 & 20 & 100 & 70 \\
\hline 7 & $+1 / 4 \mathrm{x}$ & $1 \mathrm{x}$ & $2 x$ & $+1 / 2 \mathrm{x}$ & 20 & 100 & 53 & 20 & 37 & 70 \\
\hline 8 & $+1 / 2 x$ & $2 x$ & $1 x$ & $+1 / 4 x$ & 25 & 20 & 37 & 100 & 70 & 53 \\
\hline 9 & $1 \mathrm{x}$ & $+1 / 4 \mathrm{x}$ & $+1 / 2 \mathrm{x}$ & $2 x$ & 30 & 37 & 53 & 70 & 20 & 100 \\
\hline
\end{tabular}

${ }_{\mathrm{z} P \mathrm{PF}}=$ photosynthetic photon flux.

Table 2. Specification of the individual nutrient solution concentration median and range for each "grouped" nutrient level treatment.

\begin{tabular}{lccc}
\hline \hline Variable & $\begin{array}{c}\text { Low } \\
\left(\mathrm{mg} \cdot \mathrm{L}^{-1}\right)\end{array}$ & $\begin{array}{c}\text { Medium } \\
\left(\mathrm{mg} \cdot \mathrm{L}^{-1}\right)\end{array}$ & $\begin{array}{c}\text { High } \\
\left(\mathrm{mg} \cdot \mathrm{L}^{-1}\right)\end{array}$ \\
\hline $\mathrm{N}$ Median & 40 & 80 & 160 \\
$\quad$ Range & $20-50$ & $50-110$ & $110-230$ \\
$\mathrm{P}$ & & & 90 \\
Median & 22 & 45 & $61-122$ \\
$\quad$ Range & $14-30$ & $30-61$ & 90 \\
$\mathrm{~K}$ & & & $45-135$ \\
Median & 10 & 30 & 190 \\
Range & $1-15$ & $15-45$ & $125-256$ \\
Ca & & & 60 \\
Median & 47 & 95 & $45-81$ \\
$\quad$ Range & $25-60$ & $60-125$ & \\
Mg & & 30 & \\
Median & 15 & $22-45$ & \\
Range & $8-22$ & & \\
\hline
\end{tabular}

from symmetrical locations on each bench were harvested 4 days later and were dried for plant weight and tissue analysis.

All combinations of three nutrient solution concentrations, five PPF levels, and three air temperatures were studied. Temperature was the main plot treatment with nutrient concentration and PPF as the split-plot treatments arranged in a split block with three replications (Table 1). Two days between experimental weeks were given to ensure the system reached equilibrium at the environmental levels (particularly nutrient concentration) of the following treatment (i.e., day 1 of the next week). Effects of treatments on nutrient uptake were determined using split plot-split block analysis of variance in SAS (SAS Institute, 1989).

Three concentrations of each nutrient were studied: high, medium, and low (Table 2). Data from four original "targeted" nutrient solution treatments (as shown in Table 1) were consolidated by nutrient into three "grouped" treatments. The median concentrations and ranges of the grouped treatments were selected to minimize overlap among measured concentrations at the beginning of each measurement period. Daily nutrient replenishment was required because uptake rates for each 36-plant treatment were relatively large compared to the small irrigation system volume (6.5 L). However, without foreknowledge about the uptake rates, it was difficult to return each solution to its target initial concentra- tions each day. Consolidation reduced the number of nutrient concentration treatments by one but did not affect the basic experimental design. In the original nutrient treatments, the baseline $(1 \times)$ nutrient recipe was based on generally accepted concentrations and ratios (R. McMahon, personal communication) (in $\left.\mathrm{mg} \cdot \mathrm{L}^{-1}\right): 100 \mathrm{NO}_{3}-\mathrm{N}, 30 \mathrm{P}, 100$ $\mathrm{K}, 100 \mathrm{Ca}, 30 \mathrm{Mg}, 15 \mathrm{~S}$, and 6.7 commercial micronutrient mix [Compound 111, The Scott Companies (formerly Grace Sierra) Marysville, Ohio]. The other recipes were fractions or multiples of this basic recipe. Only the $\mathrm{NO}_{3}$ form of $\mathrm{N}$ was used since only that form of $\mathrm{N}$ was measured.

The three light period/dark period set-point temperatures (in ${ }^{\circ} \mathrm{C}$ ) were $30 / 20,25 / 20$, and 20/20. Photoperiod was $12 \mathrm{~h}$ with abrupt transitions of light and temperature. The five PPF levels were created using single layers of commercial black polypropylene shade cloth above the ceiling panels and resulted in the levels and distributions shown in Table 3. PPF treatments were designated by the nominal shade cloth values (e.g., $100 \%$ level $=$ no shade cloth, $70 \%$ level $=30 \%$ shade cloth, etc.), although actual transmission varied $\leq 10 \%$ from these rated values (Table 3 ). All PPF levels were below photosynthetic saturation for New Guinea impatiens (Mankin, 1994). Shading had little effect on spectral quality and affected spatial distribution uniformly across each bench (Mankin, 1994). However, area-weighted PPF distributions on each bench often overlapped with other light treatments. For example, the 100 to $150 \mu \mathrm{mol} \cdot \mathrm{m}^{-2} \cdot \mathrm{s}^{-1}$ range covered $16 \%$ of each bench in the $53 \% \mathrm{PPF}$ treatment and $47 \%$ of each bench in the $37 \%$ treatment, but this PPF range did not occur in the $100 \%, 70 \%$, or $20 \%$ PPF treatments. Such distributions are common (although often not reported) in growth chambers. In our study, nutrient uptake was related to the mean PPF for each treatment.

Nutrient uptake was measured by the amount of nutrient depletion in the irrigation system for each treatment (i.e., the cumulative uptake from 36 plants) over a 9-h span of the light period, beginning $1 \mathrm{~h}$ after the start of the photoperiod. With continuous replacement of evaporative water loss, changes in nutrient concentration were assumed to be due solely to plant uptake. Solution samples $(10 \mathrm{ml})$ were analyzed for $\mathrm{NO}_{3}-\mathrm{N}$ using a Cardy individual ion sensor, and $\mathrm{P}, \mathrm{K}, \mathrm{Ca}$, and $\mathrm{Mg}$ were analyzed by inductively coupled plasma spectrophotometry (Mankin, 1994). Solution concentration values were converted into uptake rates per unit canopy area by Eq. [1],

$\mathrm{V}_{\mathrm{n}}=\Delta \mathrm{C}_{\mathrm{ns}} *(\mathrm{Vol} \div \mathrm{A} * \mathrm{CAI} * \Delta \mathrm{t})$

where $\mathrm{V}_{\mathrm{n}}=$ rate of nutrient uptake per unit canopy area (milligram per square meter per hour), $\Delta \mathrm{C}_{\mathrm{ns}}=$ change in nutrient solution concentration (milligram per liter), $\mathrm{Vol}=$ system volume (liters), $\mathrm{A}=$ bench area (square meter), $\mathrm{CAI}=$ canopy area index (projected canopy area to bench area ratio; square meter per square meter), and $\Delta \mathrm{t}=$ uptake period (hours).

Canopy area index (CAI) was evaluated by digitizing overhead photographs of the canopy and determining the fraction of bench area covered by plant leaves. In addition to individual nutrient 
uptake, total uptake was monitored continuously as the change in electrical conductivity (EC) within the irrigation system.

\section{Results and Discussion}

Nutrient uptake of $\mathrm{N}, \mathrm{P}, \mathrm{K}, \mathrm{Ca}$, and $\mathrm{Mg}$ increased significantly with solution concentration (Fig. 1, Table 4). All nutrients increased from low to medium concentration treatments, but only $\mathrm{K}$ increased significantly with a further increase in concentration. Uptake was not significantly related to temperature for any nutrient or to PPF for N, P, and Ca (Fig. 1, Table 4). At the two highest PPF levels, Mg was significantly greater than for the two lowest levels. Similarly, K uptake at the two highest PPF levels was significantly greater than either the $20 \%$ or $53 \%$ levels.

The response of $\mathrm{N}, \mathrm{P}$, and $\mathrm{Mg}$ uptake to solution concentration interacted with air temperature (Fig. 2, Table 4). Uptake was independent of temperature at the lowest solution concentrations but was significantly correlated with temperature at the highest concentrations. At higher temperatures, uptake increased significantly with solution concentration, although this was not always the case at $20^{\circ} \mathrm{C}$. This increase may indicate a nutrient limitation on uptake at the lowest solution concentrations that was overcome at higher concentrations. Figure 2 also makes clear that the downturn in $\mathrm{P}$ uptake shown in Fig. 1 for the highest $\mathrm{P}$ concentration was due to decreased nutrient use at $20{ }^{\circ} \mathrm{C}$ relative to the higher temperatures. Similar downward trends were evident for $\mathrm{N}$ and $\mathrm{Mg}$. The plant appeared to have been unable to use the highest nutrient solution concentrations at the lowest temperature $\left(20^{\circ} \mathrm{C}\right)$.

PPF may have been confounded by an overlap between treatments (Table 3). However, several treatments had no PPF overlap. For example, the $100 \%$ PPF treatment, which ranged from 236 to

Table 3. Spatial distribution of photosynthetic photon flux (PPF) (400 to $700 \mathrm{~nm}$ ) at canopy level. Each of the four benches received identical distributions.

\begin{tabular}{|c|c|c|c|c|c|}
\hline \multirow{2}{*}{$\begin{array}{l}\text { PPF range } \\
\left(\mu \mathrm{mol} \cdot \mathrm{m}^{-2} \cdot \mathrm{s}^{-1}\right)\end{array}$} & \multicolumn{5}{|c|}{ PPF level (rated \% transmission) } \\
\hline & 20 & 37 & 53 & 70 & 100 \\
\hline \multicolumn{6}{|c|}{ Spatial distribution of PPF at canopy level (\% of total bench area) } \\
\hline $650-700$ & & & & & 5 \\
\hline $600-650$ & & & & & 11 \\
\hline $550-600$ & & & & & 10 \\
\hline $500-550$ & & & & & 14 \\
\hline $450-500$ & & & & & 16 \\
\hline $400-450$ & & & & 12 & 13 \\
\hline $350-400$ & & & & 11 & 10 \\
\hline $300-350$ & & & 2 & 12 & 13 \\
\hline $250-300$ & & & 23 & 21 & 7 \\
\hline $200-250$ & & & 31 & 19 & 1 \\
\hline $150-200$ & & 29 & 29 & 9 & \\
\hline $100-150$ & & 47 & 16 & & \\
\hline $50-100$ & 81 & 25 & & & \\
\hline $0-50$ & 19 & & & & \\
\hline \multicolumn{6}{|c|}{ PPF at canopy level $\left(\mu \mathrm{mol} \cdot \mathrm{m}^{-2} \cdot \mathrm{s}^{-1}\right)$} \\
\hline Mean & 65 & 122 & 200 & 288 & 446 \\
\hline SD & 19 & 36 & 60 & 86 & 133 \\
\hline Maximum & 100 & 189 & 302 & 444 & 633 \\
\hline Minimum & 34 & 65 & 106 & 152 & 236 \\
\hline \multicolumn{6}{|c|}{ Total daily PPF integral at canopy level $\left(\mathrm{mol} \cdot \mathrm{m}^{-2} \cdot \mathrm{d}^{-1}\right)$} \\
\hline Mean & 2.8 & 5.3 & 8.6 & 12.3 & 19.3 \\
\hline \multicolumn{6}{|c|}{ Actual shading level (\% transmission vs. no shading, $400-700 \mathrm{~nm}$ ) } \\
\hline Mean & 15 & 27 & 45 & 65 & --- \\
\hline
\end{tabular}

$633 \mu \mathrm{mol} \cdot \mathrm{m}^{-2} \cdot \mathrm{s}^{-1} \mathrm{PPF}$, had no overlap with the $37 \%$ treatment, which ranged from 65 to $189 \mu \mathrm{mol} \cdot \mathrm{m}^{-2} \cdot \mathrm{s}^{-1}$. Similarly, $70 \%$ and $20 \%$ PPF treatments had no overlap in measured levels. The shortterm uptake response theory suggests that plants receiving higher PPF levels use nutrients at faster rates, resulting in greater uptake rates (Mankin and Fynn, 1996). Yet, even between the distinctly separate PPF treatments in this study, the relationships between uptake and PPF level generally were not significant (Fig. 1). Thus, these plants did not respond directly to near-term environment.

Uptake continued throughout the dark period as indicated by an average decrease in EC at $8.6 \pm 0.5 \mathrm{mmhos} \cdot \mathrm{cm}^{-1} \cdot \mathrm{m}^{-2} \cdot \mathrm{h}^{-1}$ (mean \pm $\mathrm{SE}$ ) in the dark compared with $8.3 \pm 0.4 \mathrm{mmhos} \cdot \mathrm{cm}^{-1} \cdot \mathrm{m}^{-2} \cdot \mathrm{h}^{-1}$ during the light period (no significant difference). In addition, darkperiod uptake was not significantly related to dark-period water uptake or previous light-period PPF (data not shown, see Mankin, 1994). This contrasted with the results of Pang (1992), who concluded that no nutrient uptake occurred during the dark period for New Guinea impatiens. The difference may be due to the more sensitive EC monitoring system used in the our study compared with that used by Pang (1992).

To verify that uptake occurred continuously for New Guinea impatiens, measured nutrient uptake was compared to nutrient accumulation in plant tissues assuming a 24-h uptake period. Shoot tissue nutrient concentrations were measured for 12 plants at the end of the experiment and were averaged. Roots were not sampled but were assumed to have similar tissue nutrient concentrations as shoots and to be $10 \%$ of the shoot dry weight. This is reasonable for annual species in moist, nonlimiting conditions

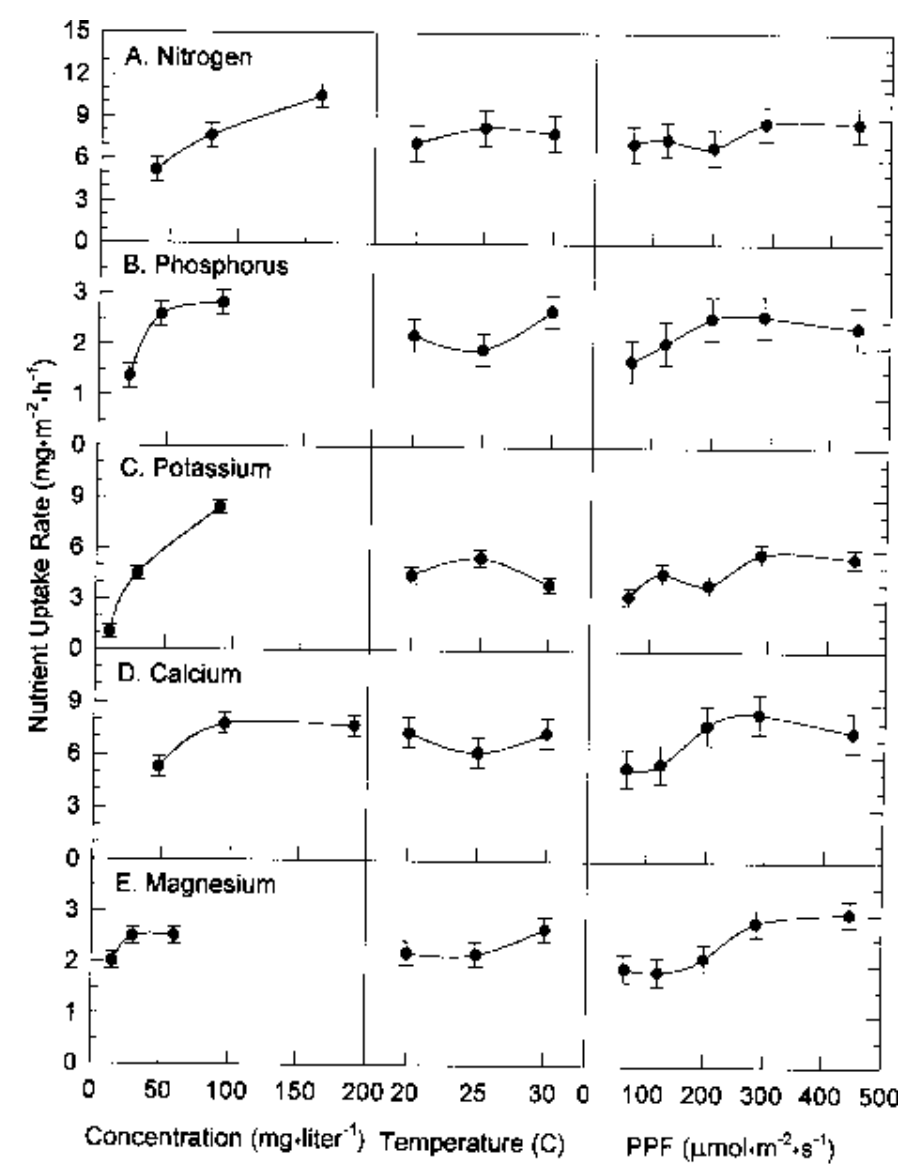

Fig. 1. Nutrient uptake rate response to nutrient solution concentration, air temperature, and photosynthetic photon flux (PPF) for (A) N, (B) P, (C) K, (D) Ca, and (E) Mg. Uptake was measured by nutrient solution depletion over $9 \mathrm{~h}$ of constant environmental conditions. Vertical bars represent SE of the means. 
(Struik and Bray, 1970). Uptake was assumed to be proportional to the degree of canopy exposure, as determined by CAI. In our experiment, average CAI was $\approx 50 \%$ of the bench area over the 118-d plant life (Mankin, 1994). Assuming an initial tissue nutrient concentration of $0 \mathrm{mg} \cdot \mathrm{L}^{-1}$, tissue concentrations were translated to net assimilation rates (NAR) by Eq. [2],

$\mathrm{NAR}=\Delta \mathrm{C}_{\mathrm{nt}} *\left(\mathrm{~W} \div \mathrm{A} * \mathrm{CAI}_{\mathrm{avg}} * \Delta \mathrm{t}\right)$

where NAR $=$ net assimilation rate of an individual nutrient per canopy area (milligram per square meter per hour), $\Delta \mathrm{C}_{\mathrm{nt}}=$ change in shoot tissue nutrient concentration on a dry-weight basis (milligram per gram), and $\mathrm{W}=$ average plant dry weight per bench (grams).

Table 4. Analysis of variance summary for daily uptake of individual nutrients.

\begin{tabular}{lccccc}
\hline \hline Effect $^{\mathrm{z}}$ & $\mathrm{N}$ & $\mathrm{P}$ & $\mathrm{K}$ & $\mathrm{Ca}$ & $\mathrm{Mg}$ \\
\hline $\mathrm{T}$ & $\mathrm{NS}$ & $\mathrm{NS}$ & $\mathrm{NS}$ & $\mathrm{NS}$ & $\mathrm{NS}$ \\
$\mathrm{L}$ & $\mathrm{NS}$ & $\mathrm{NS}$ & $*$ & $\mathrm{NS}$ & $* *$ \\
$\mathrm{~L} \times \mathrm{T}$ & $\mathrm{NS}$ & $\mathrm{NS}$ & $\mathrm{NS}$ & $\mathrm{NS}$ & $\mathrm{NS}$ \\
$\mathrm{C}$ & $* * *$ & $* * *$ & $* * *$ & $* * *$ & $* *$ \\
$\mathrm{~L} \times \mathrm{C}$ & $\mathrm{NS}$ & $\mathrm{NS}$ & $\mathrm{NS}$ & $\mathrm{NS}$ & $\mathrm{NS}$ \\
$\mathrm{T} \times \mathrm{C}$ & $*$ & $* *$ & $\mathrm{NS}$ & $\mathrm{NS}$ & $* *$ \\
$\mathrm{~L} \times \mathrm{T} \times \mathrm{C}$ & $\mathrm{NS}$ & $\mathrm{NS}$ & $\mathrm{NS}$ & $\mathrm{NS}$ & $\mathrm{NS}$
\end{tabular}

${ }_{\mathrm{zT}}=$ air temperature, $\mathrm{L}=$ light level (photosynthetic photon flux), $\mathrm{C}=$ nutrient solution concentration of specified nutrient.

ss, *, **, *** Nonsignificant or significant at $P \leq 0.05,0.01$, or 0.001 , respectively.

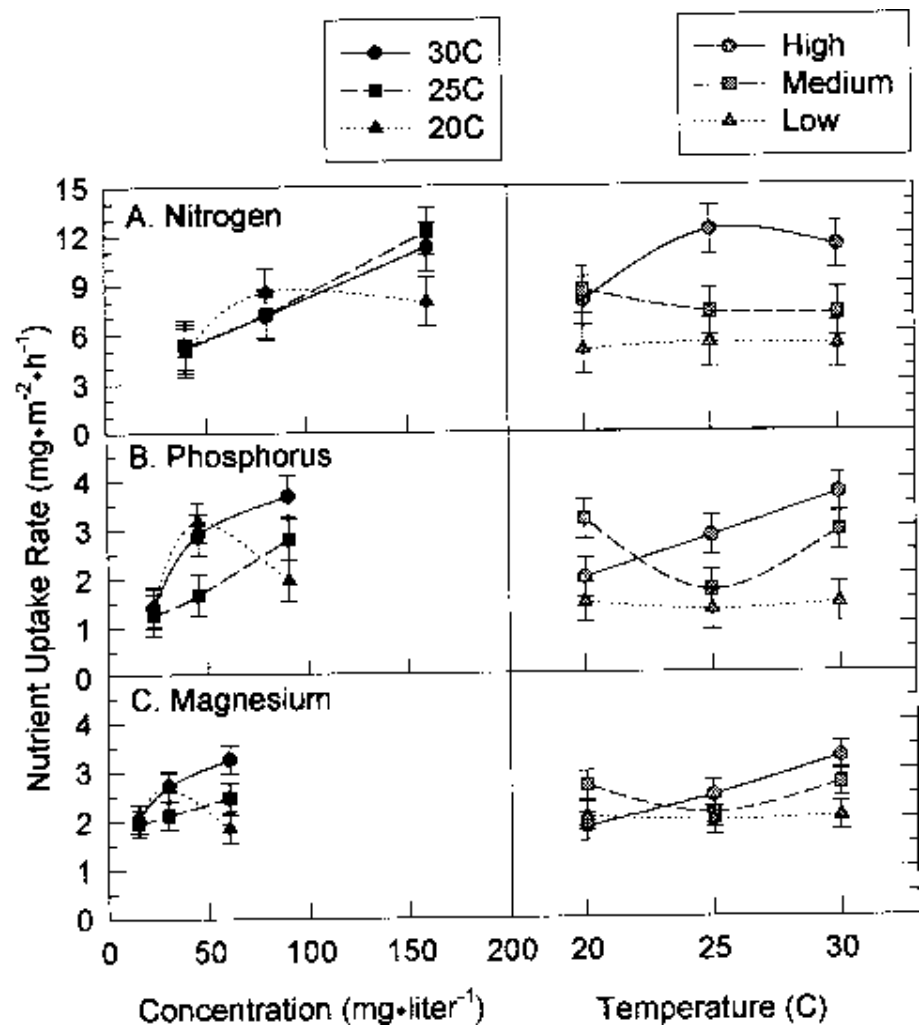

Fig. 2. Interactive effects of air temperature $\left(20,25\right.$, and $\left.30^{\circ} \mathrm{C}\right)$ and nutrient solution concentration (low, medium, and high concentrations) on nutrient uptake rate for (A) N, (B) P, and (C) Mg. Vertical bars represent SE of the means.
Using these assumptions, measured nutrient solution depletion $\left(\mathrm{V}_{\mathrm{n}}\right.$, Eq. [1]) was not significantly different from NAR (Eq. [2]) for $\mathrm{N}$, Ca, and Mg (Fig. 3). This result is consistent with continuous uptake of these nutrients at a constant average rate according to the canopy area. However, $\mathrm{V}_{\mathrm{n}}$ and NAR were significantly different for $\mathrm{P}$ and $\mathrm{K}$. The reason for these differences is not clear. Possible explanations include the following: a) in calculating NAR, the assumptions of continuous uptake, uptake proportional to CAI, and/or root weight, and nutrient concentrations, may have been appropriate for $\mathrm{N}, \mathrm{Ca}$, and $\mathrm{Mg}$ but not for $\mathrm{P}$ and $\mathrm{K}$; b) laboratory analysis may have systematically over-reported $\mathrm{P}$ and underreported $\mathrm{K}$ concentrations, although this was not likely since careful calibrations preceded each analysis; and c) the unlikely possibility that there was an unaccounted source of $\mathrm{P}$ and sink of $\mathrm{K}$ in the Haydite gravel media or elsewhere in the recirculating system.

One possible interpretation of the $\mathrm{N}, \mathrm{Ca}$, and $\mathrm{Mg}$ results is that although uptake was not sensitive to daily (short-term) variations in PPF (Fig. 1), over a longer-term period, the plant must absorb each nutrient according to the demand established by PPF-induced growth (Mankin and Fynn, 1996). This would explain the need for CAI in Eq. [2] to account for plant interception of PPF. However, this theory cannot be supported directly by data from this study since the treatments were designed to provide each bench with equal cumulative PPF integrals over the 9-week experiment and no significant differences were found in final mean plant dry weights.

The continuously recirculating irrigation system used in this study provided plant roots with a constant supply of nutrient solution, minimizing root-zone nutrient transport processes as a possible influence on nutrient uptake. This contrasts with some typical systems that have periodic irrigation and nutrient solution depletion in the root zone (e.g., Yelanich and Biernbaum, 1993). It is not clear whether differences between continuous vs. periodic nutrient replenishment would cause differences in uptake.

New Guinea impatiens in gravel culture integrated nutrient uptake over time to meet changing nutrient demands brought about by changing environmental conditions. This integrative capacity may be relatively high for succulent plants like New Guinea impatiens. Plant ability to store nutrients suggests that timing of nutrient supply to the root zone may be less important than total nutrients reaching the root zone over time, as long as demands of long-term plant growth are met. This view supports using simplified nutrient management schemes, such as preplant fertilizer and constant concentration applications, where the total amount of added nutrients are designed to meet total plant requirements.

\section{Conclusions}

Nutrient uptake of $\mathrm{N}, \mathrm{P}, \mathrm{K}, \mathrm{Ca}$, and $\mathrm{Mg}$ by New Guinea impatiens in gravel culture were not shown to be related to air temperature over 9-h photoperiods. Only uptake of K and $\mathrm{Mg}$ were correlated to PPF. Uptake increased significantly with solution $\mathrm{N}$, $\mathrm{P}, \mathrm{K}, \mathrm{Ca}$, and $\mathrm{Mg}$ concentrations. These results do not support the hypothesis relating short-term (daily or less) uptake of nutrients to the demand established by the current levels of environmental characteristics that affect growth. However, comparisons of measured nutrient uptake to final tissue nutrient concentrations indicated that long-term uptake of $\mathrm{N}, \mathrm{Ca}$, and $\mathrm{Mg}$ may be related to canopy area, leaf area, or dry weight. This suggests that although uptake of individual nutrients was not related to concurrent daily levels of PPF and temperature, demand may affect or control uptake of specific nutrients over the life of a plant.

Our experiment studied the response of New Guinea impatiens 


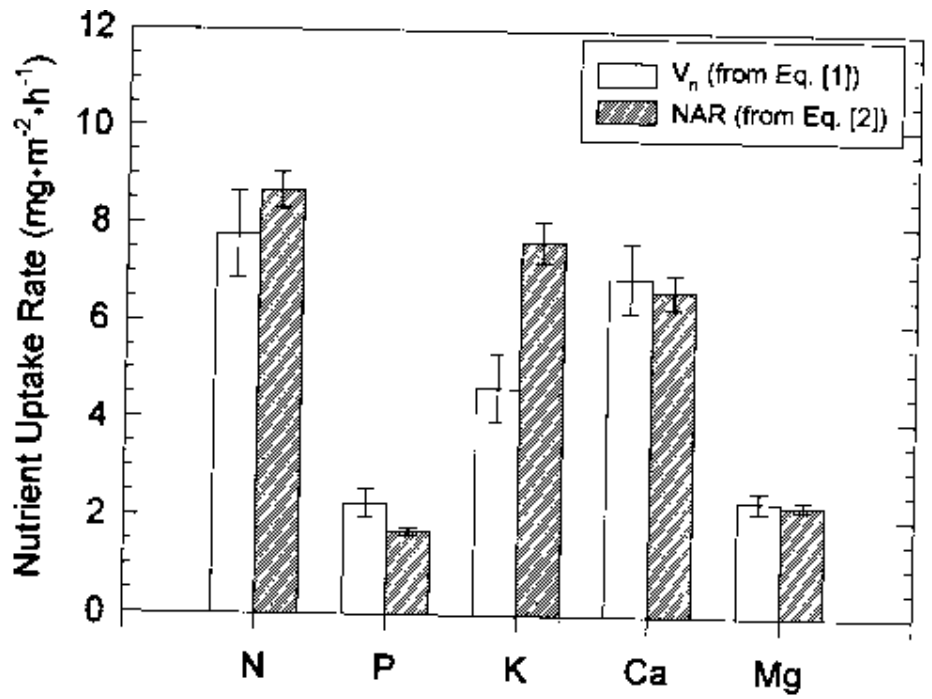

Fig. 3. Comparison of individual nutrient uptake rates predicted by measured nutrient solution depletion $\left(\mathrm{V}_{\mathrm{n}}\right)$ and by measured tissue concentrations [net assimilation rates (NAR)]. NAR was calculated from shoot tissue nutrient concentrations assuming: roots were $10 \%$ of shoot mass with similar tissue concentrations, a 24-h uptake period, and uptake proportional to the average percentage of canopy exposure (canopy area index) over the 118-d plant life. Vertical bars represent $95 \%$ confidence intervals.

to relatively short-term environmental conditions: daily changes in PPF and weekly changes in air temperature and nutrient solution concentration. The conclusion that nutrient uptake was not affected by short-term (daily) changes in the environment is significant for the greenhouse industry. If this result is able to be generalized to other plant types and growing systems, growers would not need to be concerned with fine-tuning the prediction of nutrient demand according to short-term fluctuation in environment (e.g., daily or hourly weather, transient clouds). In addition, developers of new, computer, fertilizer control systems would not need to model short-term fluctuations in plant demand or develop software or hardware to accommodate such fluctuations.

\section{Literature Cited}

American Society of Agricultural Engineers. 1986. ASAE engineering practice: EP411.1; Guidelines for measuring and reporting environmental parameters for plant experiments in growth chambers. American Society of Agricultural Engineers, St. Joseph, Mich.

Biernbaum, J. and W. Fonteno. 1989. Minimize groundwater contamination. Greenhouse Grower 7(2):90-92, 94-95.

Bloom, A.J., F.S. Chapin, and H.A. Mooney. 1985. Resource limitations in plants-An economic analogy. Annu. Rev. Ecol. Systematics 16:363392.

Epstein, E. 1973. Mechanisms of ion transport through plant cell membranes. Intl. Rev. of Cytology 34:123-168.

Mankin, K.R. and R.P. Fynn. 1996. Modeling individual nutrient uptake by plants: Relating demand to microclimate. Agr. Systems J. 50:101114.

Mankin, K.R. 1994. Modeling nutrient and water uptake responses to the environment by New Guinea impatiens. PhD Diss., Dept. of Agricultural Engineering, The Ohio State Univ., Columbus.

McAvoy, R.J., M.H. Brand, E.G. Corbett, J.W. Bartok, Jr., and A. Botacchi. 1992. Effect of leachate fraction on nitrate loading to the soil profile underlying a greenhouse crop. J. Environ. Hort. 10:167-171.

Morisot, A., G.C. Montanaro, and J.P. Tournier. 1978. Distribution of fertilizer elements in the soil of floral greenhouses in southern France (carnation and rose). Ann. Agron. 29:177-192. Translated by K.B. Mankin.

Nissen, P. 1991. Multiphasic uptake mechanisms in plants. Intl. Rev. of Cytology 126:89-134.

Pang, T. 1992. Dynamic analysis of water and nutrient uptake for New Guinea impatiens. PhD Diss., Dept. Agricultural Engineering, The Ohio State Univ., Columbus.

SAS Institute. 1989. SAS/STAT user's guide, Version 6, 4th ed., Vol. 1. SAS Inst., Cary, N.C.

Struik, G.J. and J.R. Bray. 1970. Root-shoot ratios of native forest herbs and Zea mays at different soil-moisture levels. Ecology 51:892-893.

Willits, D.H., P.V. Nelson, M.M. Peet, M.A. Depa, and J.S. Kuehny. 1992. Modeling nutrient uptake in chrysanthemum as a function of growth rate. J. Amer. Soc. Hort. Sci. 117:769-774.

Yelanich, M.V. and J.A. Biernbaum. 1993. Root-zone nutrient concentration and growth of poinsettia at three fertilizer concentrations and four leaching fractions. J. Amer. Soc. Hort. Sci. 118:771-776. 